\title{
Macrolide analog F806 suppresses esophageal squamous cell carcinoma (ESCC) by blocking $\beta 1$ integrin activation
}

\author{
Li-Yan Li ${ }^{1,2, *}$, Hong Jiang ${ }^{3, *}$, Yang-Min Xie ${ }^{4}$, Lian-Di Liao ${ }^{1,2}$, Hui-Hui Cao ${ }^{1,2}$, Xiu-E Xu ${ }^{1,2}$, \\ Bo Chen ${ }^{1,2}$, Fa-Min Zeng ${ }^{1,5}$, Ying-Li Zhang ${ }^{1,2}$, Ze-Peng Du ${ }^{1,2}$, Hong Chen ${ }^{3}$, Wei Huang ${ }^{3}$, \\ Wei Jia ${ }^{3}$, Wei Zheng ${ }^{3}$, Jian-Jun Xie ${ }^{1,5}$, En-Min Li ${ }^{1,5}$, Li-Yan Xu ${ }^{1,2}$ \\ ${ }^{1}$ The Key Laboratory of Molecular Biology for High Cancer Incidence Coastal Chaoshan Area, Shantou University Medical \\ College, Shantou, Guangdong, P.R. China \\ ${ }^{2}$ Institute of Oncologic Pathology, Shantou University Medical College, Shantou, Guangdong, P.R. China \\ ${ }^{3}$ Fujian Key Laboratory of Screening for Novel Microbial Products, Fujian Institute of Microbiology, Fuzhou, Fujian, P.R. China \\ ${ }^{4}$ Experimental Animal Center, Shantou University Medical College, Shantou, Guangdong, P.R. China \\ ${ }^{5}$ Department of Biochemistry and Molecular Biology, Shantou University Medical College, Shantou, Guangdong, P.R. China \\ *These authors have contributed equally to this work
}

Correspondence to:

Li-Yan Xu, e-mail: lyxu@stu.edu.cn

En-Min Li, e-mail: nmli@stu.edu.cn

Keywords: macrolide analog F806, $\beta 1$ integrin, cell adhesion, anoikis, esophageal squamous cell carcinoma cells

Received: January 21, $2015 \quad$ Accepted: March 14, $2015 \quad$ Published: April 03, 2015

\section{ABSTRACT}

The paucity of new drugs for the treatment of esophageal squamous cell carcinoma (ESCC) limits the treatment options. This study characterized the therapeutic efficacy and action mechanism of a novel natural macrolide compound F806 in human ESCC xenograft models and cell lines. F806 inhibited growth of ESCC, most importantly, it displayed fewer undesirable side effects on normal tissues in two human ESCC xenograft models. F806 inhibited proliferation of six ESCC cells lines, with the half maximal inhibitory concentration $\left(\mathrm{IC}_{50}\right)$ ranging from 9.31 to $16.43 \mu \mathrm{M}$. Furthermore, F806 induced apoptosis of ESCC cells, contributing to its growth-inhibitory effect. Also, F806 inhibited cell adhesion resulting in anoikis. Mechanistic studies revealed that F806 inhibited the activation of $\beta 1$ integrin in part by binding to a novel site Arg610 of $\beta 1$ integrin, suppressed focal adhesion formation, decreased cell adhesion to extracellular matrix and eventually triggered apoptosis. We concluded that $\mathbf{F 8 0 6}$ would potentially be a well-tolerated anticancer drug by targeting $\beta 1$ integrin, resulting in anoikis in ESCC cells.

\section{INTRODUCTION}

Esophageal squamous cell carcinoma (ESCC), the major histologic form of esophageal cancer, is one of the most frequent fatal malignancies worldwide and the fourth leading cause of cancer-related death in China [1]. Despite aggressive treatment modalities such as surgical resection with extensive lymphadenectomy and surgery combined with chemotherapy and/or radiotherapy, survival of ESCC patients with recurrence or metastasis remains poor $[2,3]$. Therefore, novel safe and effective therapeutic strategies such as the utilization of targeted therapy drugs are highly desirable for the patients with ESCC.
Remarkable advances in cancer molecular biology and pathogenesis have recently led to successful development of myriad mechanism-based targeted therapies that substantially improve survival and quality of life for cancer patients [4]. The vanguard of novel anticancer drugs often targets cellular signaling mechanisms, aberrant tumor stroma, and tumor vasculature and microenvironment [5-7]. Intracellular signaling network which are propagated from the cell surface to intracellular processes, comprising extracellular ligands, transmembrane receptors and cytoplasmic secondary messengers, often optimizes tumor growth and metastasis in malignancies, and represents potential selective targets 
for cancer therapy [8]. Integrins are a family of the heterodimeric cell surface receptors that bind to the cell extracellular matrix (ECM), promote the transmission of multiple signaling pathways, and coordinate extensive broad range of functional activities, such as cell growth, survival, adhesion, invasion and metastasis [9, 10]. Eighteen $\alpha$-subunits and eight $\beta$-subunits assemble into 24 different integrins [11]. Among these integrins, $\beta 1$ integrin has recently been shown to play a key role in regulating the switch from a dormant state to active proliferation and metastasis, and confer therapeutic resistance in multiple solid cancer models [12-16]. Importantly, it has been reported several possible therapeutic approaches, such as small molecules or inhibitory antibodies, directing against $\beta 1$ integrin signaling to prevent the recurrence of cancer in experimental models [17-19]. However, $\beta 1$ integrin as a strategic molecular target of a novel chemotherapeutic agent has not been well investigated in ESCC.

The natural compound F806, also named FW-04-806 is isolated by fermentation of soil Streptomyces sp. FIM-04-806, and possesses both bioxazole and macrodiolide chemical structures (Supplementary Figure 1) [20, 21]. Our previous study has been reported that F806 exhibited potent activity against human cancer cells [22]. In the current study, we investigated the anti-cancer effect of F806 in ESCC cells in vivo and in vitro, and the biological activity of F806 against ESCC cells by blocking $\beta 1$ integrin activation.

\section{RESULTS}

\section{F806 inhibits tumor growth in EC109 and KYSE510 tumor xenograft models}

To assess the antitumor potential of F806 in xenograft models, EC109 and KYSE510 esophageal squamous cell carcinoma (ESCC) cells were inoculated subcutaneously into nude mice. Three groups of xenograft mice were intraperitoneally administered with vehicle (control), $4 \mathrm{mg} / \mathrm{kg}$ and $8 \mathrm{mg} / \mathrm{kg} \mathrm{F} 806$ daily for 21 days respectively and sacrificed at the end. The data showed that tumors from both of F806-treated groups grew more slowly than the control group (Figure 1A and 1B). In detail, no significant difference of the tumor volume in each group was observed at the beginning of treatment. However, a significant $(P<0.05)$ antitumor effect of F806 was displayed in EC109 and KYSE510 xenograft models beginning at day $8 / 9$ after the start of treatment. At the end of treatment, $4 \mathrm{mg} / \mathrm{kg}$ or $8 \mathrm{mg} / \mathrm{kg} \mathrm{F} 806$ reduced tumor growth by $55.0 \%(P=0.015)$ or $47.2 \%(P=0.035)$ in EC109 cells, and $62.2 \%(P=0.003)$ or $75.9 \%(P=0.000)$ in KYSE510 cells, as compared to the control group.

Simultaneously, the safety of F806 was evaluated in xenograft mice. All mice tolerated this treatment well without toxic symptoms or signs and had stable body weights during the treatment (Figure 1A and 1B, lower panel). No significance of biochemical markers for liver and renal function was found between F806-treated and control mice (Supplementary Table 3). No effect on complete blood count including white blood, red blood, hemoglobin and blood platelet count, was observed between F806-treated and control mice (Supplementary Table 4). In addition, no histological abnormality was shown in lungs, brains, liver, heart and kidneys of mice between F806-treated and control groups at the end of drug treatment (Figure 1C). Together, these data suggest that F806 effectively inhibits tumor growth in the absence of drug-induced adverse effects.

\section{F806 inhibits cell proliferation in various ESCC cells}

To assess the effects of F806 on cell growth, cell viability was determined by MTT assay in various ESCC cell lines, including EC109, KYSE70, KYSE450, KYSE150, KYSE180, and KYSE510 cells. Meanwhile, as a positive control, the growth of MTLn3 rat mammary adenocarcinoma cell was inhibited by F806 with $72 \mathrm{hr}$ $\mathrm{IC}_{50}$ value of $9.60 \mu \mathrm{M}$, which is consistent with a previous report [22]. Shown in cell viability assays on ESCC cells, rounding and detachment of cultured cells increased in a dose- $(0-40 \mu \mathrm{M})$ and time-dependent $(0-72 \mathrm{~h})$ manner after treatment with F806 (the morphology features of EC109 cells as shown in Supplementary Figure 2). The growth-inhibitory effect of F806 was tested in various ESCC cell lines at $72 \mathrm{hr}$, with $\mathrm{IC}_{50}$ values of 16.43, 15.89, 10.94, 10.50, 10.28 and 9.31 $\mu \mathrm{M}$ in EC109, KYSE70, KYSE450, KYSE150, KYSE180, and KYSE510 cells respectively (Figure 2A). Notably F806 demonstrated potent growth-inhibitory effects against ESCC cells.

\section{F806 induces cell apoptosis in ESCC cells}

We next examined whether the growth-inhibitory effect of F806 was due to apoptosis. Transmission electron microscopy revealed condensation and margination of nuclear chromatin surrounding in the nucleus of EC109 cells treated with F806 for $24 \mathrm{hr}$, which is strongly suggestive of apoptotic cell death (Figure 2B). An apoptotic phenotype was further supported by DNA laddering, a specific marker for cell apoptosis (Figure 2C) in F806-treated EC109 cells. On the other hand, cell cycle analysis presented the presence of a sub-G1 DNA peak in F806-treated EC109 cells (Figure 2D). Furthermore, the apoptosis precursor (ADP-ribose) polymerase (PARP) was cleaved, along with the reduction of PARP and the increase of cleaved PARP in F806-treated ESCC cells (Figure 2E). To further confirm the F806-induced apoptosis in ESCC cells, tumor sections from xenograft models were stained for nuclear apoptosis using the DeadEnd Fluorometric TUNEL reagent staining (Figure $2 \mathrm{~F}$ ). In contrast to control group, tumors from the F806-treated group 
A

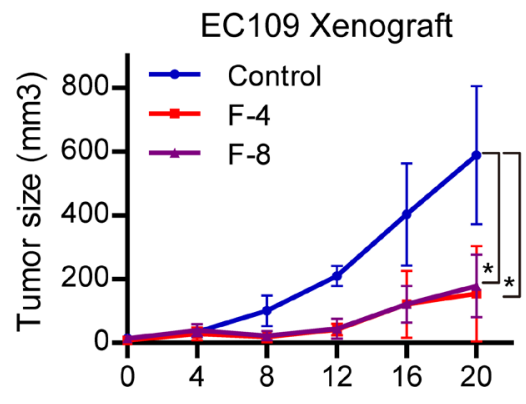

Days post drug administration
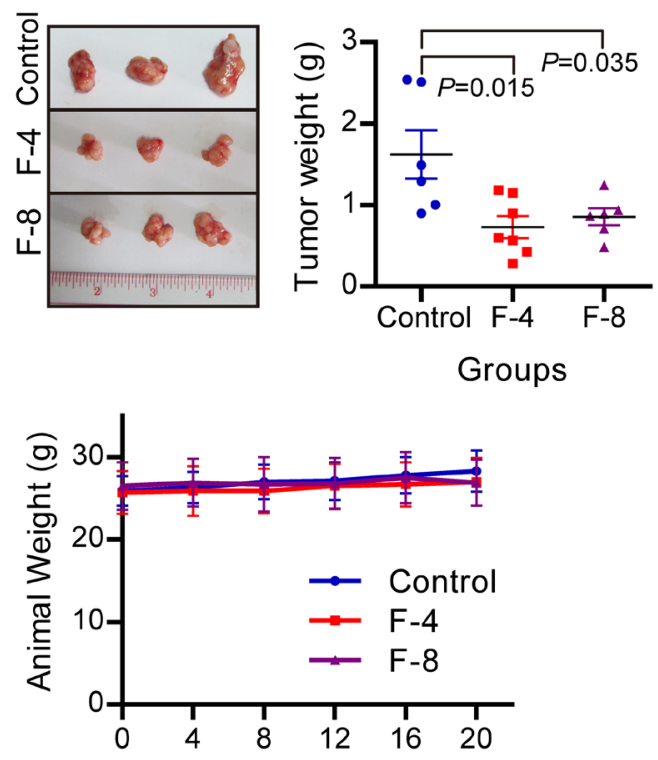

Days post drug administration
B

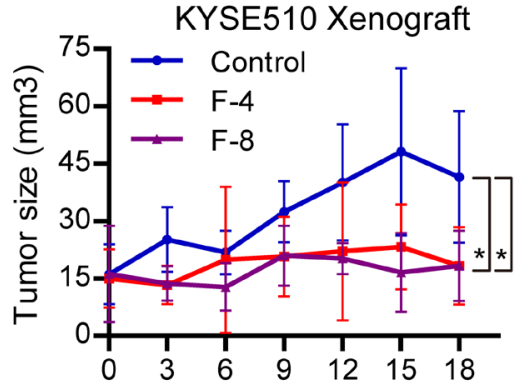

Days post drug administration
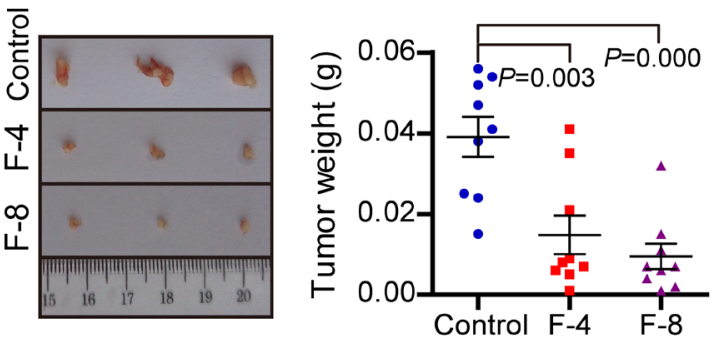

Groups

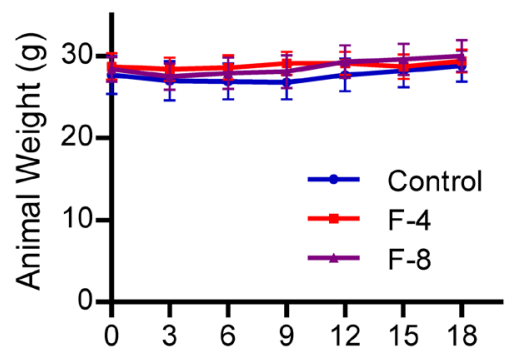

Days post drug administration
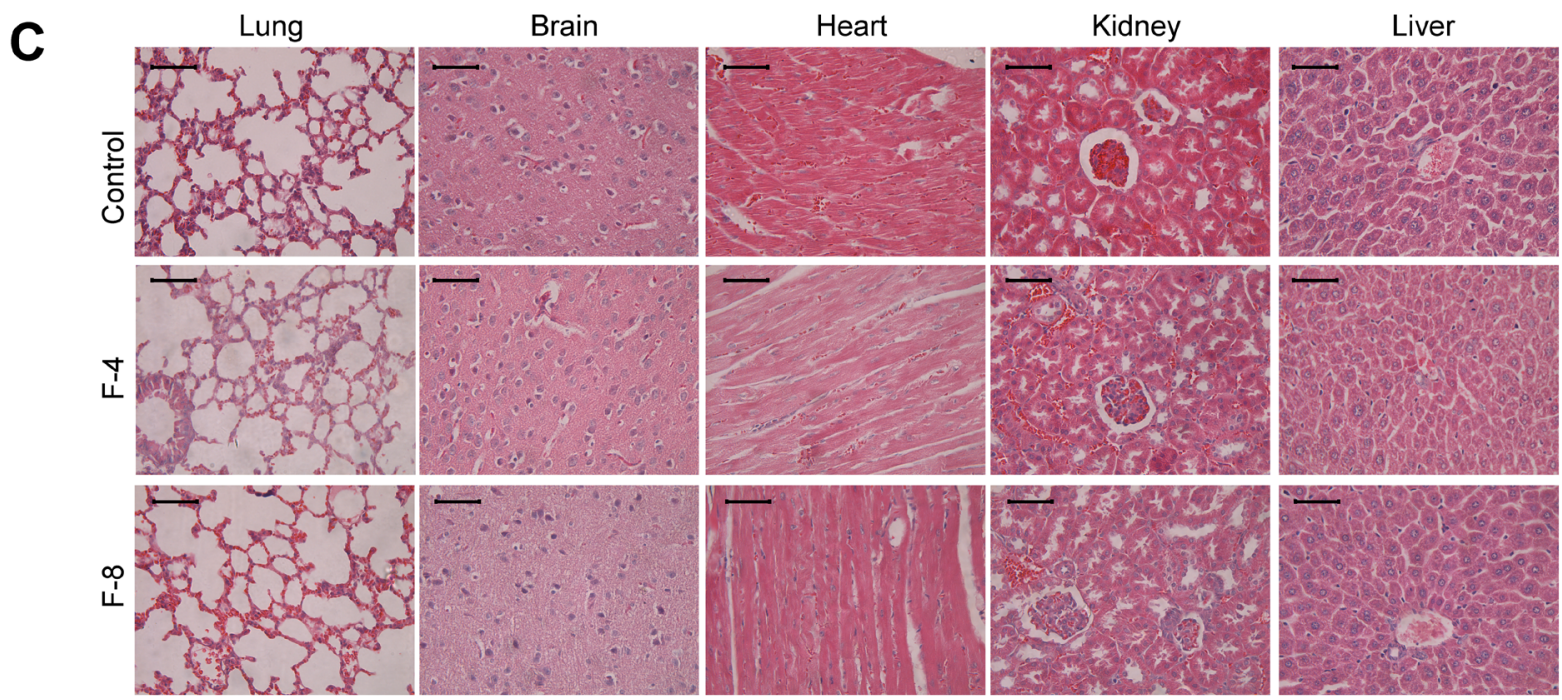

Figure 1: Anti-tumor effect and low toxicity of F806 in ESCC xenograft tumor models. A. and B. F806 inhibited tumor growth of ESCC xenograft models with low toxicity. Upper panel: Tumor volume growth curve of xenograft models in control and treated groups. Middle panel: Weight and representative pictures of the excised tumors on day 22 in control and treated groups. Lower panel: Body weight curve of xenograft mice in treated and control groups. C. Representative Hematoxylin-eosin staining for potential toxicity of F806 in lung, brain, heart, kidney and liver of F806-treated mice. Scale bar $=50 \mu \mathrm{m}$. ${ }^{*} P<0.05 v s$. control mice; mean $\pm \mathrm{SD}, n=7$; F-4, F806-4 mg/kg; F-8, F806-8 mg/kg. 
A

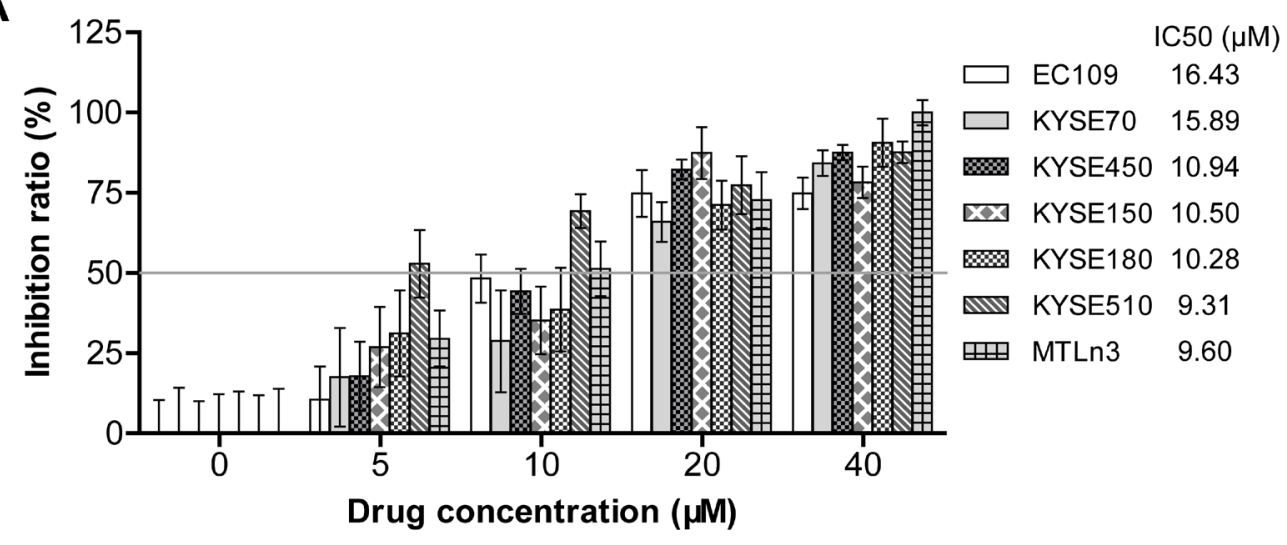

B

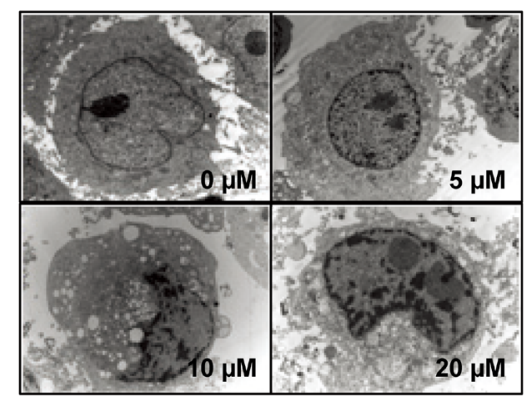

C

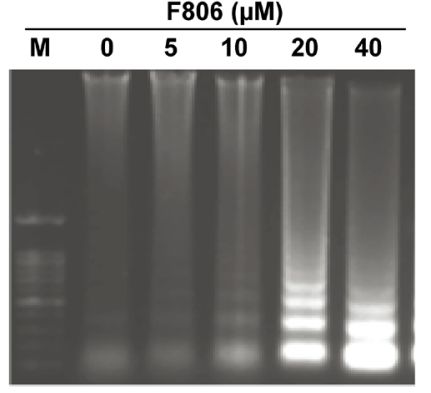

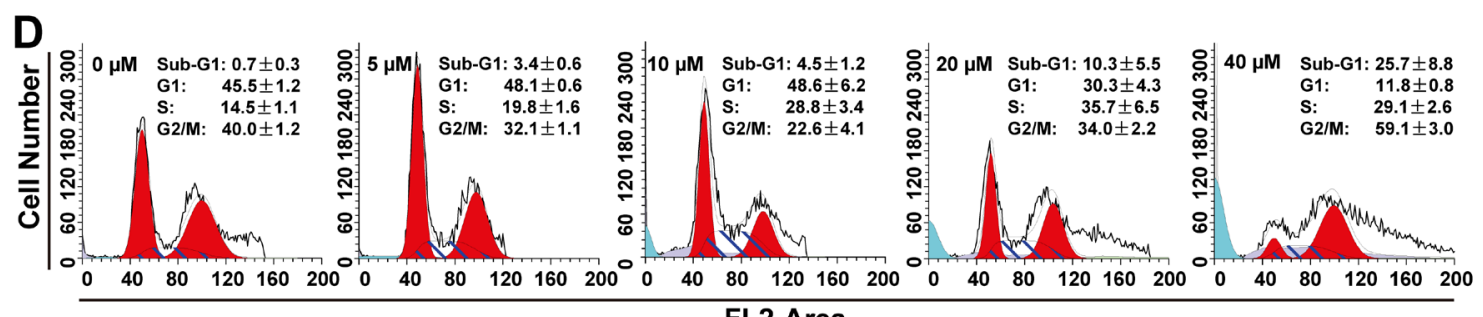

FL2-Area

$\mathbf{E}$
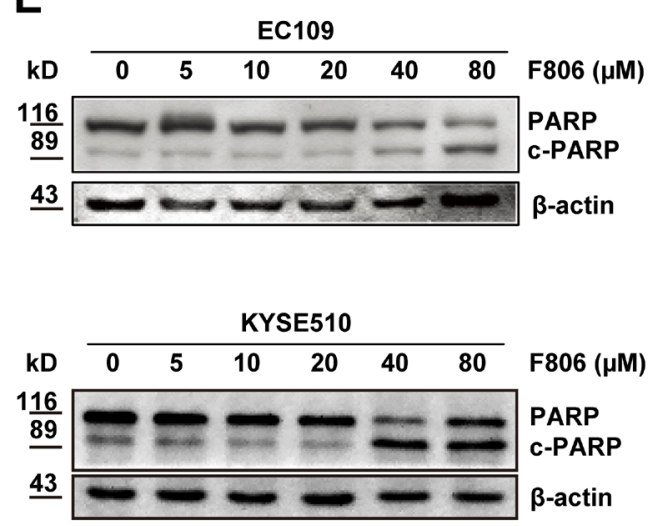
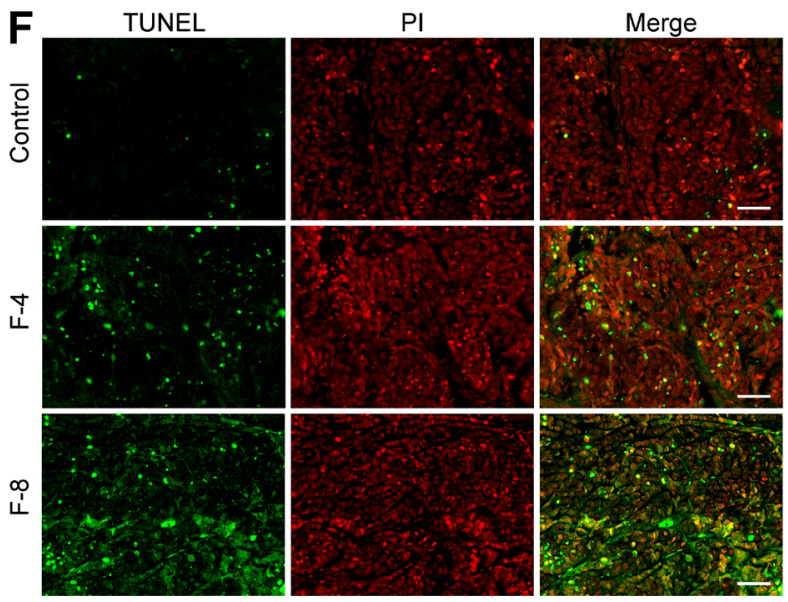

Figure 2: F806 inhibits growth and induces apoptosis in ESCC cells. Various ESCC cells were treated with 0 - $40 \mu \mathrm{M} \mathrm{F806} \mathrm{for}$ 24 or 72 hours. A. F806 inhibited proliferation of ESCC cells with $\mathrm{IC}_{50}$ values ranging from 9.31 to $16.43 \mu \mathrm{M}$. Proliferation was measured by MTT assay, and the $72 \mathrm{hr} \mathrm{IC}$ of F806 was evaluated. Mean $\pm \mathrm{SD} ; n=12$. B. Morphological changes of apoptosis were observed by transmission electron microscopy of F806-treated EC109 cells (original magnification, 30,000×). C. DNA laddering in F806-treated EC109 cells. D. Flow cytometry shows the appearance of a sub-G1 peak in F806-treated EC109 cells. Mean \pm SD, $n=6$. E. Western blot analysis for execution of apoptosis in F806-treated ESCC cells. F. paraffin-embedded tumor tissues from xenograft models were subjected to DeadEnd Fluorometric TUNEL-assay for detection of apoptosis. The TUNEL-positive cells are visualized in green fluorescence in a red (PI) background by fluorescence microscopy (Original magnification, 400×). F-4, F806-4 mg/kg; F-8, F806-8 mg/kg. 
showed obvious nuclear condensation and DNA fragment staining. Thus, F806 would induce apoptosis, contributing to growth inhibition and cell death in ESCC cells.

\section{F806 inhibits cell adhesion and sensitizes ESCC cells to anoikis}

ESCC cells, as epithelial cells, require attachment to an appropriate extracellular matrix (ECM) in order to survive [23]. Interestingly, we noted that ESCC cells began to round up and detach after $24 \mathrm{hr}$ of F806treatment, however, visible inhibition of growth was not observed until $48 \mathrm{hr}$ after treatment. After $48 \mathrm{hr}$ and $72 \mathrm{hr}$ of treatment, the adherent cells significantly decreased, while the floating dead cells increased (Supplementary Figure 2). These results clued that F806 inhibited cell adhesion, resulting in the induction of apoptosis in a process named 'anoikis' [24]. When EC109 and KYSE510 cells were cultured in poly-HEMA plates in presence of F806, a significant induction of anoikis in a dose-dependent manner was found (Figure 3A). Additionally, the effect of F806 on cell adhesion was investigated in different ECM conditions and different treatments. As shown in Figure 3B, F806 significantly inhibited cell adhesion, while there was no selectivity on fibronectin (FN), collagen (COL) or laminin (LAM). Furthermore, when EC109 and KYSE510 cells were kept in FN or COL-coated plates for $30 \mathrm{~min}$ and treated with F806 for another $24 \mathrm{~h}$ (Figure 3C), or kept for $24 \mathrm{~h}$ prior to $30 \mathrm{~min}$ of F806 stimulation (Figure 3D), cell adhesion was still significantly inhibited. These data indicated that F806 clearly inhibited cell adhesion, indicating anoikis.

\section{F806 inhibits focal adhesion formation in ESCC cells}

The results of anoikis led us to the hypothesis that adhesion complex formation might be inhibited in ESCC cells by F806. To investigate the effect of F806 on adhesion complex formation, focal adhesion marker Paxillin and Kindlin-2 was detected F806-treated cells by immunofluorescence staining. After cells on FN, COL or LAM-coated coverslips treated with F806 for $24 \mathrm{hr}$, focal adhesion were clearly observed in the basal
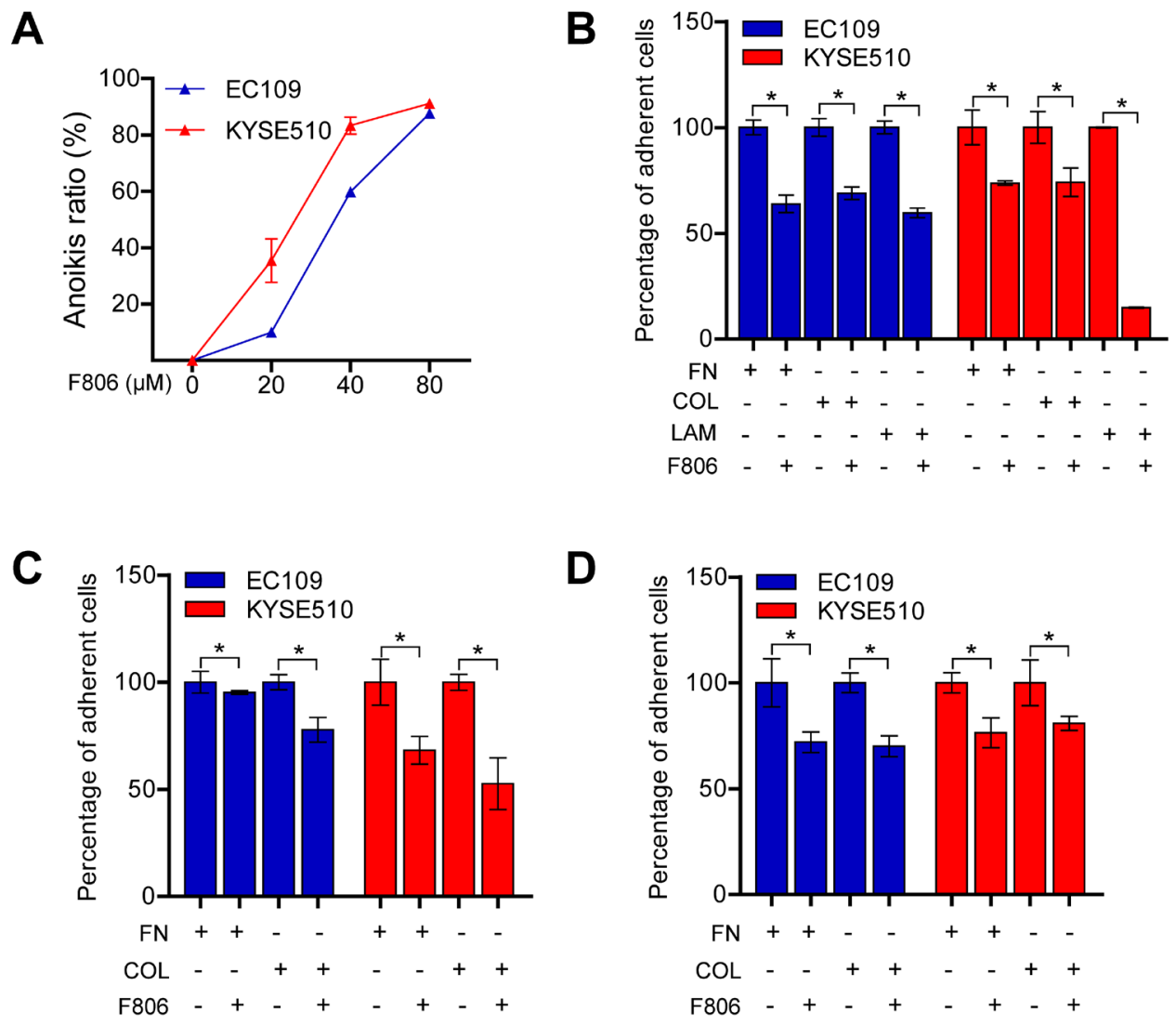

Figure 3: F806 inhibits cell adhesions and induces anoikis in ESCC cells. A. EC109 and KYSE510 cells were suspension cultured on poly-HEMA-coated plates in the presence of F806 for $48 \mathrm{~h}$ and anoikis ratio was then determined by MTT assay. B. EC109 and KYSE510 cells were kept in fibronectin (FN), collagen (COL) or laminin (LAM)-coated plates in the presence of F806 for 24 h. C. EC109 and KYSE510 cells were kept in FN or COL-coated plates for 30 min and treated with F806 for another 24 h. D. EC109 and KYSE510 cells were kept in FN or COL-coated plates for $24 \mathrm{~h}$ prior to $30 \mathrm{~min}$ of F806 stimulation. The attached cells were recorded by MTT assay in each group. Data represent three independent experiments; $* P<0.05 v s$. control group; mean $\pm \mathrm{SD}, n=3-6$. 
layer of cells and the cell shapes remained normal in the control group, however, focal adhesion formation were obviously inhibited in F806-treated group (Figure 4A and $4 \mathrm{~B}$, left panel). The observations were supported by experiments on both of focal adhesion marker Paxillin and Kindlin-2. Additionally, the effect of F806 on expression of Paxillin and Kindlin-2 were evaluated by Western blot. As shown in Figure 4A and 4B, right panel, compared to the control, no difference on expression of Paxillin and Kindlin-2 were found in F806-treated cells. Therefore, F806 inhibited focal adhesion formation of ESCC cells and consequently inhibited cells to attach to ECM.

\section{F806 blocks the activation of $\beta 1$ integrin in ESCC cells}

We next investigated the potential mechanism of F806 involved in the inhibition of cell adhesion. Previous studies have shown that integrins mediate cells to ECM and promote the transmission of multiple signaling pathways for the initiation of cell proliferation, including ERK/MAPK and PI3K/AKT $[25,26]$. Western blot analysis revealed that no apparent effect on the total protein level of $\beta 1$ integrin, $\beta 4$ integrin and $\alpha 5$ integrin was observed; nevertheless, F806 inhibited
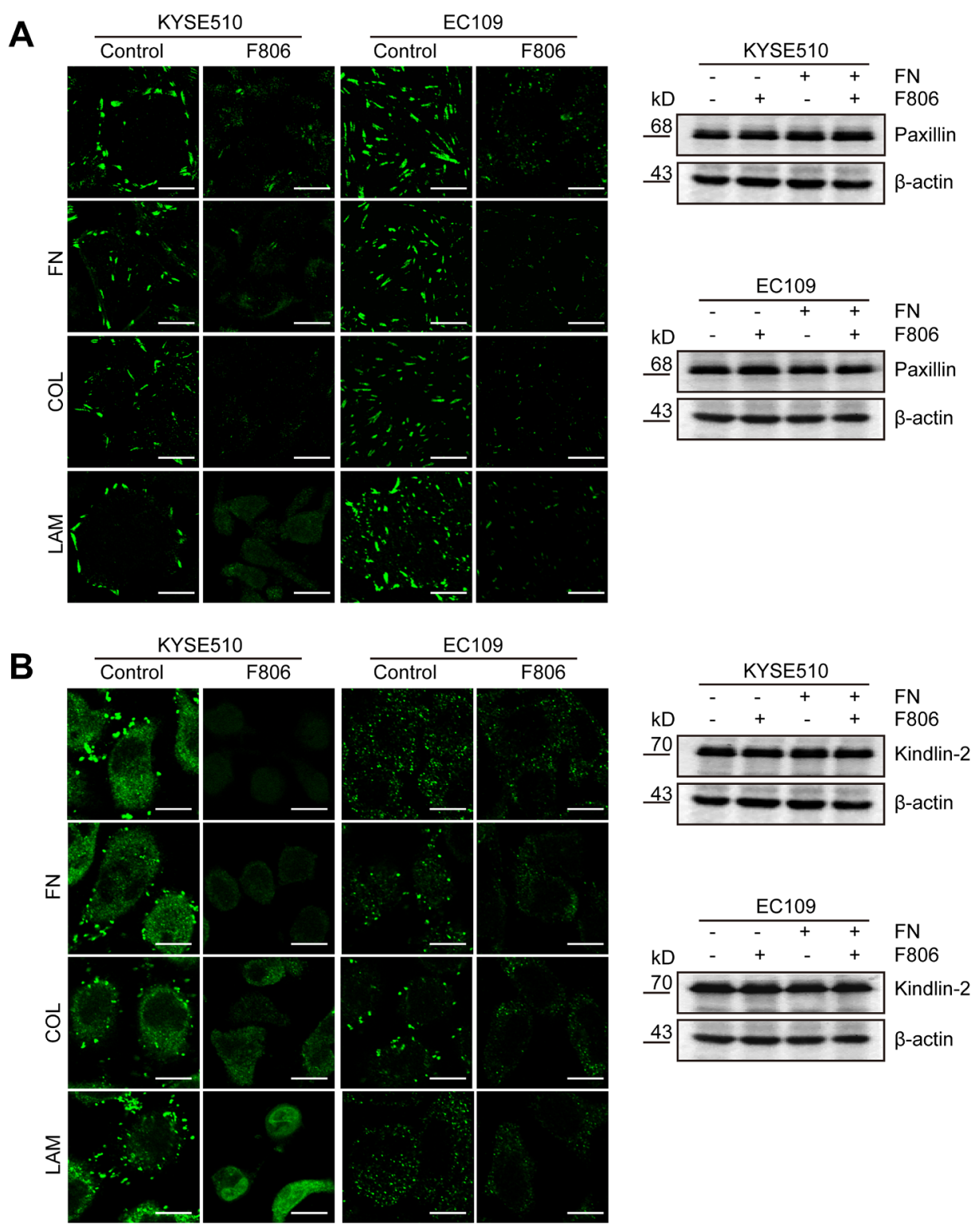

Figure 4: F806 inhibits focal adhesion formation in ESCC cells. EC109 and KYSE510 cells were kept in FN, COL or LAM-coated coverslips in the presence of F806 for $24 \mathrm{~h}$. A. Cells on coverslips were analyzed by immunofluorescent staining for focal adhesion marker Paxillin (left panel). Whole-cell lysates were immunoblotted for anti-Paxillin and $\beta$-actin (right panel). B. Cells on coverslips were analyzed by immunofluorescent staining for another focal adhesion marker Kindlin-2 (left panel). Whole-cell lysates were immunoblotted for anti-Kindlin-2 and $\beta$-actin (right panel). Original magnification, 1200×; Scale bar, $20 \mu \mathrm{m}$. 
$\beta 1$ integrin activation in KYSE510 and EC109 cells by immunoprecipitation (Figure 5A). Moreover, tumor sections from xenograft models were immunochemistry stained for active $\beta 1$ integrin. Compared to control group, tumors from the F806-treated group showed obvious inhibition of active $\beta 1$ integrin (Figure 5B). To provide further evidence, we examined signal molecules known to be activated in the downstream of integrin signaling. Decreases in levels of activated FAK (p-FAK), AKT (p-AKT) and ERK1/2 (p-ERK1/2) were observed in F806treated ESCC cells (Figure 5C).

To determine whether F806 inhibited the activation of $\beta 1$ integrin, resulting in inhibition of cell adhesion and inducing anoikis, the blockade of the activation of $\beta 1$ integrin using specific antibody JB1A and down-regulation of $\beta 1$ integrin by siRNA were examined to mimic the effect of F806. As shown in Figure 5D, the blockade of the activation of $\beta 1$ integrin inhibited cell adhesion in KYSE510 cells; however, F806 was more effective and the combination of anti- $\beta 1$ integrin with F806 caused the most suppression of cell adhesion. Furthermore, knockdown of $\beta 1$ integrin by siRNA certainly decreased the number of cell adhesion; nevertheless, F806 still was more effective. Importantly, after the knockdown of $\beta 1$ integrin, mounting inhibition ratio of cell adhesion was found in F806treated KYSE510 cells (Figure 5E). Collectively, it can be concluded that F806 would inhibit the activation of $\beta 1$ integrin, leading to inhibition of focal adhesion formation and cell adhesion, finally triggering apoptosis.

\section{DISCUSSION}

This study reported on the efficacy and mechanism of action of a novel macrolide analog F806 in preclinical models of esophageal squamous cell carcinoma (ESCC). Anticancer activity of F806 was evaluated in two human ESCC xenograft models and in six ESCC cell lines. Our data showed principle mechanisms for how F806 inhibited the growth in ESCC cells: F806 decreased the activation of $\beta 1$ integrin, prevented cancer cells away from the ECM, and eventually initiated apoptosis (Figure 6).

In 1979, Westley JW et al. reported the isolation of the novel compound conglobatin from fermentation cultures of Streptomyces conglobatus ATCC 31005, which has the same molecular formula as F806; however, antifungal, antibacterial, antiprotozoal, or antitumor activity remained unclear [27]. F806, also named FW-04-806, was extracted from the China-native Streptomyces FIM-04-806 and demonstrated potent anticancer activity in K562 human chronic myelocytic leukemia cells, SKBR3 and MCF-7 human breast cancer cells [20-22]. In the present study, F806 displays promising antitumor activity in ESCC cells and showed very low toxicity to the non-cancerous cells. Notably, F806 reduced the volume of ESCC xenografts at a $4 \mathrm{mg} / \mathrm{kg} / \mathrm{d}$ dose by intraperitoneal administration, which is far below the reported minimal dose of $50 \mathrm{mg} / \mathrm{kg}$ [22]. The lower dose in the treatment of ESCC models representative of lower toxicity, is a prerequisite for a successful pharmacological agent against cancer. Indeed, F806 exhibited good safety during the treatment in ESCC xenografts: no abnormality in body weight, daily diet, liver and renal function, hematological indices, and histological characteristics in the lungs, brain, heart, kidney and liver tissue, were observed (Figure 1C, Supplementary Tables 3 and 4). Considering that the in vivo experiments was performed only with xenograft models in this study, the efficacy and safety of F806 should be further investigated in spontaneous human cancer models.

Our previous study reported that F806, could bind to the N-terminal of Hsp90 and inhibit Hsp90/Cdc37 interaction, resulting in the disassociation of Hsp90/ Cdc37/client complexes and the degradation of Hsp90 client proteins in breast cancer cells [22]. Here our observations suggested that another novel anti-cancer mechanism of F806 would exist in ESCC cells. Firstly, cell growth of ESCC cells were inhibited owing to the induction of apoptosis, which was supported by multiple evidences including the DNA laddering, the condensation and margination of nuclear chromatin surrounding through transmission electron microscope. However, cells started floating after $24 \mathrm{hr}$ of treatment, while the inhibition of growth was not visibly observed until $48 \mathrm{hr}$ after the treatment. This phenomenon provided clues for the hypothesis of detachment as a cause of growth inhibition and apoptosis in F806-treated ESCC cells. Indeed, anoikis induction contributed to the potent antitumor effects of F806, as evidenced by inhibition of cell adhesion to the ECM components including FN, COL and LAM. Furthermore, the inhibition of focal adhesion formation was detected by immunofluorescence, which confirmed the results. These results strongly supported the notion that F806 attenuated cell adhesion, contributing to the inhibition of cell growth, i.e., anoikis.

Upon adhesion to ECMs, integrins as a large family of heterodimeric cell surface receptors, govern cellECM interactions and mediate cell adhesion and provide critical signaling that regulates cellular proliferation and survival $[25,26,28]$. Previous observations proposed that chemopreventive drugs or small molecules would induce apoptosis by modulating integrin-mediated signaling $[29,30]$. In our present study, no apparent effect on the protein level of $\beta 1$ integrin, $\beta 4$ integrin and $\alpha 5$ integrin was observed; nevertheless, the activation of $\beta 1$ integrin was inhibited by F806 both in vitro and in vivo. Activation of integrins is essential for cell adhesion and matrix assembly [11]. An increase in the proportion of heterodimers adopting high-affinity comformation (the affinity of integrins for their ligands) was termed integrin activation [31]. It has been widely accepted 
A

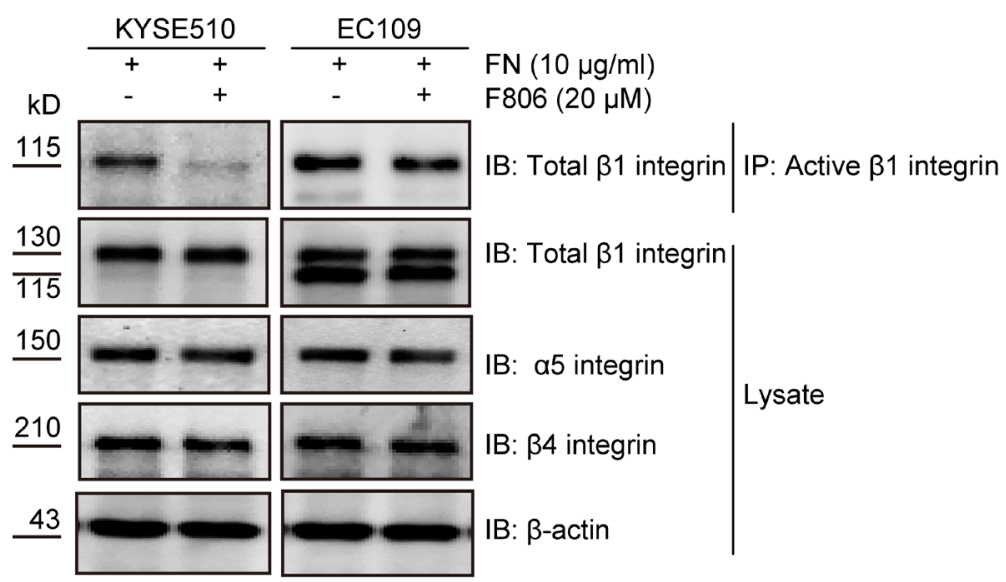

B
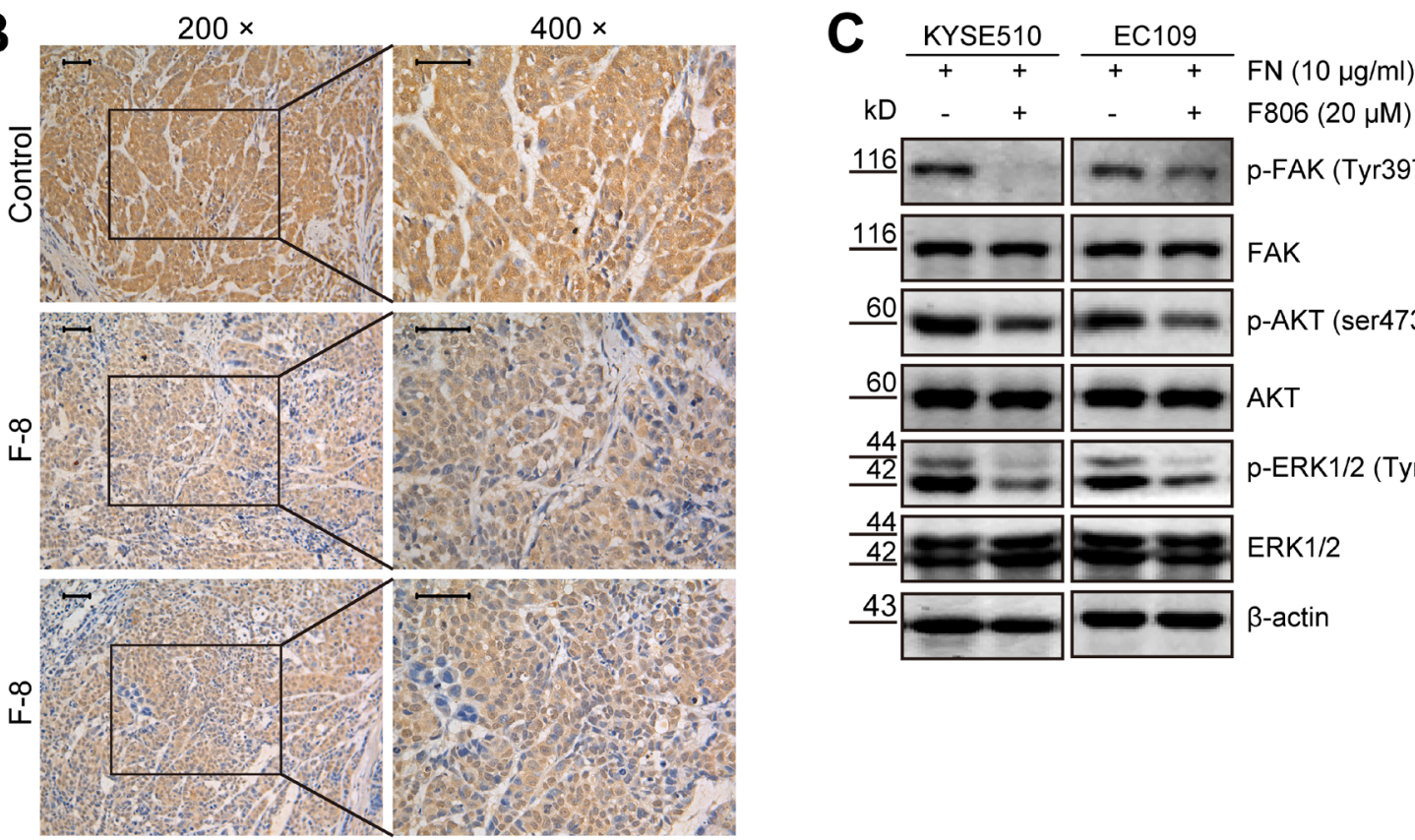

$\mathrm{kD}-+\quad+\quad \mathrm{F} 806(20 \mu \mathrm{M})$
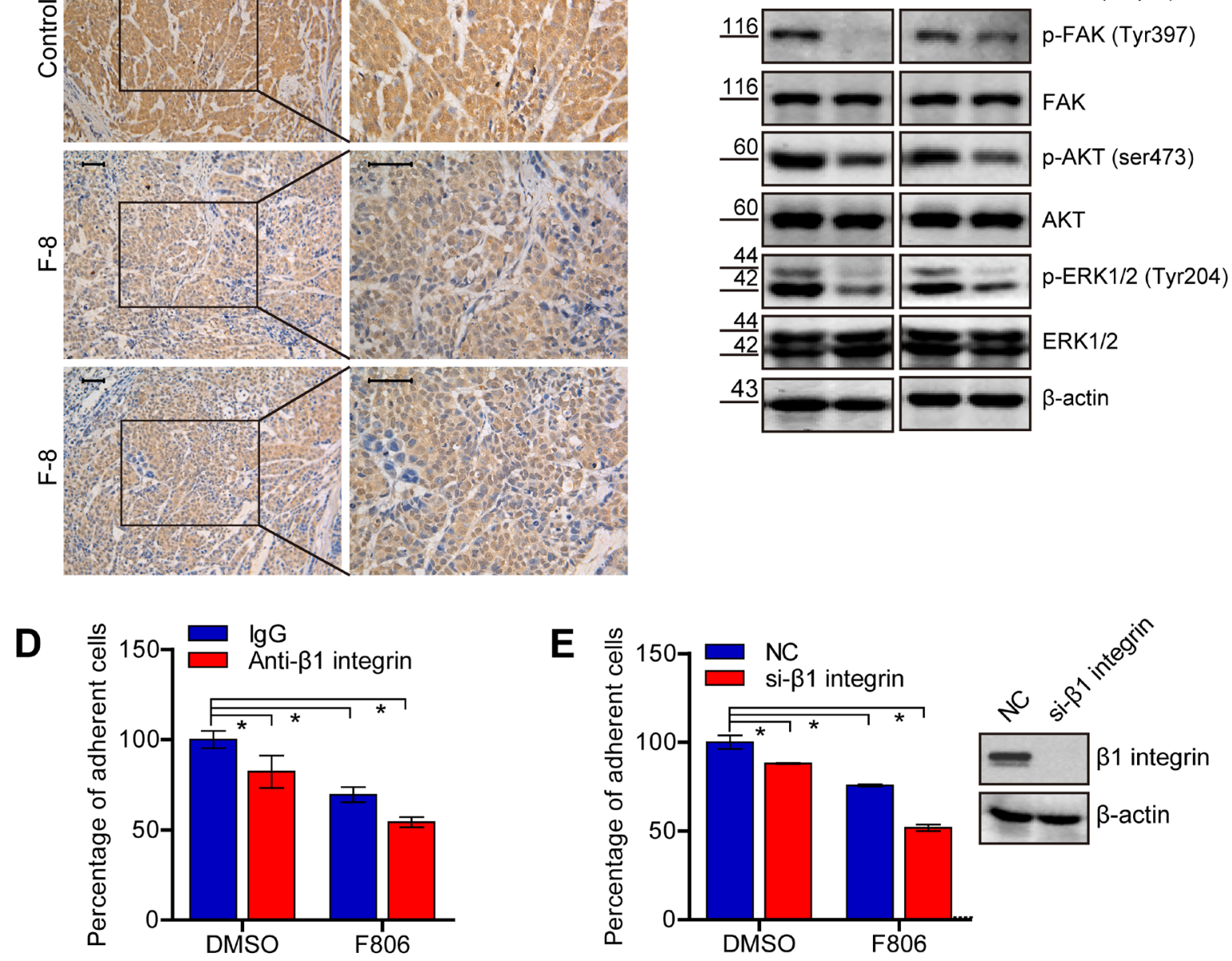

Figure 5: F806 inhibits $\beta 1$ integrin activation in ESCC cells. A. Cell lysates were immunoprecipitated (IP) with anti-active $\beta 1$ integrin antibody followed by probing with anti-total $\beta 1$ integrin antibody. Total cell lysates were immunoblotted for anti-total $\beta 1$ integrin, $\alpha 5$-integrin, $\beta 4$-integrin and $\beta$-actin. B. Paraffin-embedded tumor tissues from xenograft models were immunohistochemistry staining for anti-active $\beta 1$ integrin. Original magnification, 400×; Scale bar, $50 \mu \mathrm{m}$. C. Total cell lysates were immunoblotted for anti-p-FAK, FAK, p-AKT, AKT, p-ERK, ERK and $\beta$-actin. D. KYSE 510 cells were pre-incubated with anti- $\beta 1$ integrin or control IgG for 30 min and then seeded into FN-coated plates in the presence of F806 for $24 \mathrm{hr}$. The attached cells were recorded by MTT assay in each group. E. After si-NC or si- $\beta 1$ integrin transfection for $48 \mathrm{hr}$, KYSE5 10 cells were kept in FN-coated plates in the presence of F806 for $24 \mathrm{hr}$. The attached cells were recorded by MTT assay in each group. ${ }^{*} P<0.05$ vs. control group; mean $\pm \mathrm{SD}, n=3-6$. 


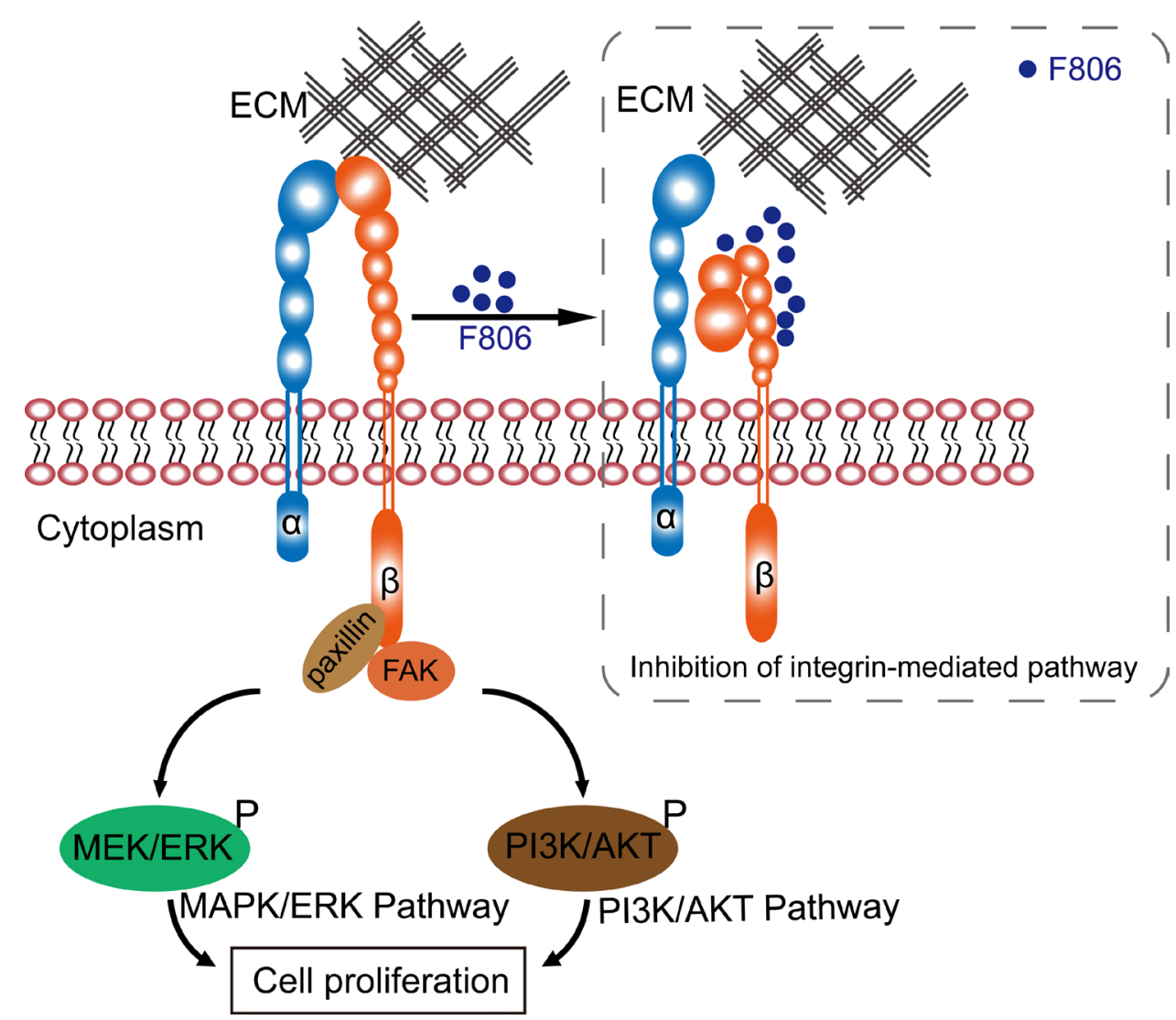

Figure 6: Schematic graph of the anti-cancer mechanism of F806.

that the binding of Talins and Kindlins to $\beta 1$ integrin is critical for integrin activation [32-33]. Therefore, the inactivation of $\beta 1$ integrin would in part inhibit the affinity of integrins for their ligands, resulting in anoikis. Classically, $\beta 1$ integrin acts largely as mechanoreceptors, not only facilitating growth factor receptor signaling, but also transmitting biochemical cues that mediate multiple aspects of malignant cell behavior [34, 35]. These roles of $\beta 1$ integrin prompt us to identify it as a potential target of F806 in ESCC cells. The decrease in the downstream signal molecules (such as p-FAK, p-AKT and p-ERK1/2) of integrin signaling confirmed the suppression of $\beta 1$ integrin activation by F806 in ESCC cells.

The specific blockade of $\beta 1$ integrin antibody was performed to determine whether the inhibition of $\beta 1$ integrin activation by F806 resulted in suppression of cell adhesion and inducing anoikis. It was showed that F806 revealed greater inhibitory effect on cell adhesion in ESCC cells, in contrast to specific anti- $\beta 1$ integrin JB1A. Nevertheless, the combination of F806 with JB1A could cause the most suppression of cell adhesion in ESCC cells (Figure 5D). The potential synergistic effect of F806 and JB1A on the inhibition of cell adhesion hinted different binding site between F806 and JB1A. Anti- $\beta 1$ integrin JB1A was recently mapped to recognize and bind residues $82-87$ of $\beta 1$ integrin chain, leading to the inhibition of cell adhesion [36]. Based on these observations, docking computation model was performed to predict possible F806-binding site of $\beta 1$ integrin. Indeed, it was presented that F806 would interact with Arg610 site of $\beta 1$ integrin by pi bond ( $\pi$ bond) (Supplementary Figure 3). However, detailed investigation might be necessary to clarify the mechanism of the interaction between F806 and Arg610 site of $\beta 1$ integrin.

Our study also showed that the knockdown of $\beta 1$ integrin indeed decreased cell adhesion in KYSE510 cells, while F806 still was more effective than si- $\beta 1$ integrin. Intriguingly, after the remarkable knockdown of $\beta 1$ integrin, mounting inhibition ratio of cell adhesion was found in F806-treated KYSE510 cells (Figure 5E). Obviously, after the loss of the target molecule $\beta 1$ integrin by si-RNA, F806 still could suppress KYSE510 cells binding to ECM. It hinted that $\beta 1$ integrin would not be the only potential target of F806 in ESCC cells. Among the 24 different integrins, there are eight $\beta$-subunits [11]. Furthermore, other integrins has been highly attractive target in oncology therapy, such as that cilengitide is an RGD pentapeptide inhibitor of $\alpha \mathrm{V}$ integrin against glioblastoma [37]. Therefore, F806 might also direct or indirect against other integrin subunit and further 
investigations would be warranted to verify the detailed mechanism.

Mounting experimental evidence supports that drug resistance of a targeted therapeutic agent can be acquired, because inhibition of one key pathway in a tumor may not completely turn off other parallel signaling pathways, allowing some cancer cells to survive and propagate. On this basis, Hanahan and Weinberg proposed that it could be necessary to target as many key pathways as possible, to prevent the development of adaptive resistance [38]. Potent angiogenesis inhibitors such as bevacizumab, has succeeded in suppressing tumor growth in clinical or preclinical models. However, acquired resistance can develop, resulting in increased invasion and local metastasis [39-43]. Integrin $\beta 1$ signaling mediates therapeutic resistance in multiple solid cancer models [12-14]. Furthermore, targeting $\beta 1$ integrin inhibits tumor growth in bevacizumab-resistant glioblastoma [13]. In this study, it was clearly demonstrated that F806 could induce apoptosis and inhibit cell growth via blocking the activation of $\beta 1$ integrin. It implies that F806 could overcome resistance to antiangiogenesis therapy and would be of potential use in combination with angiogenesis inhibitors.

In summary, our data indicate that the novel drug F806 revealed promising antitumor activity in ESCC models and showed very low toxicity to the non-cancerous cells. In addition, this study highlights the inhibition of $\beta 1$ integrin activation as a potential mechanism of F806, contributing to the suppression of focal adhesion formation, the prevention of further tumor growth and survival from the ECM, and the eventual initiation of apoptosis (i.e., anoikis) in ESCC cells. Therefore, F806 merits further evaluation and precise delineation as a therapeutic agent against human ESCC.

\section{MATERIALS AND METHODS}

\section{Chemicals and cell lines}

The compound F806, also named FW-04-806 (purity $\geq 98.5 \%$ ), was produced by Fujian Institute of Microbiology, China (Supplementary Figure 1) [20, 21]. It was dissolved in DMSO at $100 \mathrm{mM}$ as a stock solution and further diluted in medium before each use. The characteristics of the seven squamous cell carcinoma cell lines prepared for this study and general information are shown in Supplementary Table 1. All cells were incubated at $37^{\circ} \mathrm{C}$ in a humidified atmosphere containing $5 \% \mathrm{CO}_{2}$.

\section{Efficacy and safety of F806 in xenograft models}

Five-week-old male Nude/Nude mice were purchased from Vital River Laboratories (Beijing, China) and maintained on a $12 \mathrm{hr}$ light/dark cycle under specific pathogen-free conditions, with free access to food and water. All animal studies were conducted in accordance with protocols approved by the Animal Research Committee of the Shantou Administration Center. Mice were inoculated subcutaneously with $1.0 \times 10^{6}$ EC109 or $1.0 \times 10^{6}$ KYSE510 human esophageal squamous cell carcinoma (ESCC) cells on the right flank. The next day, mice were randomized to three groups of 10 mice per group. Tumor growth was monitored daily, and tumor size was measured at (length $\times$ width $\left.^{2}\right) \times 0.5$ twice per week. At approximately day 12 post tumor cell injection, when the tumor volume reached approximately $0.5 \mathrm{~mm}$ in diameter, drug administration was initiated. Mice with a tumor volume of $<0.1 \mathrm{~mm}$ or $>1.0 \mathrm{~mm}$ in diameter were excluded from drug treatment. Briefly, a $100 \mathrm{mg} / \mathrm{ml}$ F806 stock solution was prepared in 100\% ethyl alcohol. On the day of injection, F806 was diluted in $0.9 \% \mathrm{NaCl}$ containing 5\% Tween-80 and 5\% polyethylene glycol-400 (Sigma, St Louis MO, USA) to a final concentration such that a dose of $4 \mathrm{mg} / \mathrm{kg}$ or $8 \mathrm{mg} / \mathrm{kg}$, in $200 \mu \mathrm{L}$ solution, was administered to each mouse. F806 solution was intraperitoneally administered daily for 21 days. Mice were euthanized on day 22 and blood was collected for biochemical analysis or complete blood count (including differential and platelet counts). Tumors were excised, weighed, and preserved in formalin for histological analysis. The lungs, liver, heart, brains and kidneys were harvested and evaluated histologically.

\section{Cell viability assay}

Cells inoculated in 96-well plates were treated with different concentrations of F806 for $72 \mathrm{hr}$. Changes in cell morphology were documented by photography every $24 \mathrm{hr}$. Cell viability was measured using a 3-(4, 5-dimethylthiazol-2-yl)-2, 5-diphenyltetrazolium bromide (MTT) proliferation kit (Sigma, St. Louis, USA) at $72 \mathrm{hr}$, as described by the manufacturer. The formed crystals were dissolved in dimethylsulfoxide and optical density (OD) in each well was measured at a method of dual-wavelength of $490 \mathrm{~nm}$ using a microplate reader. Inhibition of growth was expressed as an inhibition ratio $(\%)=\left(1-\right.$ OD $490_{\text {Treated }} /$ OD490 $\left.{ }_{\text {Control }}\right) \times 100$ or a growth ratio $(\%)=$ OD $490_{\text {Treated }} / \mathrm{OD} 490_{\text {Control }} \times 100$. The half maximal inhibitory concentration $\left(\mathrm{IC}_{50}\right)$ was calculated from the inhibition ratio and F806 concentration by SPSS 13.0 software.

\section{Observation by transmission electron microscopy}

Cells treated with F806 for $24 \mathrm{hr}$ were pre-fixed in $2 \%$ cacodylate-buffered glutaraldehyde, post-fixed in $1 \%$ osmium tetroxide, dehydrated in a graded series of alcohol, and embedded in epon. Sections were stained 
with uranyl acetate and lead citrate, and were examined with a JEM-1400 transmission electron microscope (JEOL, Japan).

\section{Dna ladder assay}

Cells treated with F806 for $24 \mathrm{hr}$ were harvested and the DNA was extracted with the Apoptotic DNA Ladder Kit (Beyotime Institute of Biotechnology, Shanghai, China) according to the manufacturer's protocol. DNA was analyzed by $1 \%$ agarose gel electrophoresis and visualized under UV light.

\section{Cell cycle analysis}

Cells treated with F806 for $24 \mathrm{hr}$ were harvested and were fixed with $70 \%$ cold ethanol in PBS at $4^{\circ} \mathrm{C}$ overnight. Subsequently, the samples were permeabilized in phosphate-buffered saline (PBS) with $0.1 \%$ Triton $\mathrm{X}-100$ and stained again with a solution containing $5 \mu \mathrm{g} / \mathrm{mL}$ propidium iodide (PI) and $50 \mu \mathrm{g} / \mathrm{mL}$ RNase, for $30 \mathrm{~min}$ at room temperature in the dark. Finally, the samples were immediately analyzed by flow cytometry using a Coulter Epics XL flow cytometer (BeckmanCoulter Inc, Brea, CA, USA). Fluorescence emitted from the PI-DNA complex was determined by FlowJo software (TreeStar, San Carlos, CA, USA). Cell cycle distribution was calculated using Multicycle software (Phoenix Flow Systems, San Diego, CA, USA).

\section{Western blot analysis}

After cells were treated with F806 for $24 \mathrm{hr}$, total cell lysates were prepared in Laemmli sample buffer (Bio-Rad, 101-0737, Hercules, CA, USA). Western blots were performed as described previously [44]. Primary antibodies to ERK1/2, $\alpha 5$ integrin, $\beta 4$ integrin and $\beta$-actin were purchased from Santa Cruz Biotechnology (Santa Cruz, CA, USA), while antibodies to PARP, phosphoERK1/2 (p-ERK1/2, Tyr204), phospho-AKT (p-AKT, Ser473) and AKT were purchased from Cell Signaling Technology (Danvers, MA, USA), along with phosphoFAK (p-FAK, Tyr397) from Invitrogen (Camarillo, CA, USA), Kindlin-2 from OriGene Technologies ( Rockville, MD, USA), FAK, paxillin, and $\beta 1$ integrin from BD Transduction Laboratories (Franklin Lakes, New Jersey, USA). Appropriate HRP-conjugated secondary antibodies were from Santa Cruz Biotechnology (Dallas, Texas, USA). Detailed information about the antibodies is listed in Supplementary Table 2.

\section{Terminal deoxynucleotidyl transferase-mediated dUTP nick end labeling (TUNEL) assay}

The DeadEnd ${ }^{\mathrm{TM}}$ Fluorometric TUNEL System (Promega, Madison, USA) was used to detect apoptosis in paraffin-embedded tumor tissues following the manufacturer's protocol. These tissue sections were subsequently stained for nuclei with $500 \mathrm{ng} / \mathrm{mL}$ propidium iodide (PI). The samples were immediately analyzed under a fluorescence microscope using a standard fluorescent filter set to view the green fluorescence at $520 \mathrm{~nm}$ and red fluorescence of PI at $>620 \mathrm{~nm}$. The slides were imaged using an Openlab controlled microscope.

\section{Anoikis assay}

For determination of anoikis, $2 \times 10^{5}$ cells were cultured on 24-well plates coated with poly (2-hydroxyethyl methacrylate) (poly-HEMA) (Cell Biolabs, Inc., CBA-080, San Diego, CA, USA) in presence of various F806 for $72 \mathrm{hr}$. Cell viability was determined by MTT colorimetric detection and presented as mean percentage of control sample plus or minus standard deviation (SD). All experiments were performed in triplicate.

\section{Adhesion assay}

Ninety-six well plates were coated with Fibronectin (10 $\mu \mathrm{g} / \mathrm{mL}$, Sigma, F-2006, St. Louis, MO, USA), Collagen IV $(10 \mu \mathrm{g} / \mathrm{mL}$, Sigma, C-7521) or Laminin (10 $\mu \mathrm{g} / \mathrm{mL}$, Sigma, L-2020) at $4^{\circ} \mathrm{C}$ overnight. After removal of excess coating buffer and one wash with $\mathrm{PBS}$, nonspecific binding sites were blocked for $1 \mathrm{hr}$ in $0.1 \%$ bovine serum albumin (BSA) in phosphate-buffered saline (PBS) at room temperature, following with a second wash with PBS. EC109 and KYSE510 cells $\left(2 \times 10^{4}\right)$ in $100 \mu \mathrm{L}$ serum-free medium with or without F806 per well, were allowed to adhere for $24 \mathrm{hr}$ at $37 \mathrm{C}$ in a humidified 5\% $\mathrm{CO} 2$ incubator. In the adhesion inhibition assay, antibody JB1A against the $\beta 1$ integrin (1:100, Millipore, MAB1965, Bedford, MA) blocking cell adhesion to Fibronectin, was added to KYSE510 cells for $30 \mathrm{~min}$ prior to seeding. Nonspecific adherent cells were removed by washing with PBS three times. Adherent cells were subsequently measured by MTT colorimetric detection. Cell adhesion was presented as mean percentage of control sample plus or minus standard deviation (SD). All experiments were performed in triplicate.

\section{Immunofluorescence}

Cells grown on coverslips coated or uncoated with $10 \mu \mathrm{g} / \mathrm{mL}$ fibronectin, collagen IV or Laminin at $4^{\circ} \mathrm{C}$ overnight, were treated with F806 for $24 \mathrm{hr}$. After incubation, cells were fixed with $4 \%$ paraformaldehyde in PBS for $20 \mathrm{~min}$, and permeabilized with $0.1 \%$ Triton $\mathrm{X}-100$ in PBS for $10 \mathrm{~min}$. After blocking with 5\% donkey serum in PBS for $60 \mathrm{~min}$, cells were stained with mouse anti-paxillin or mouse anti-kindlin- 2 at $4{ }^{\circ} \mathrm{C}$ overnight. After washing, samples were incubated with Alexa Fluor 488-AffiniPure Donkey anti-mouse IgG (Jackson, 711-545-150, Newmarket, Suffolk, UK, 1:200). 
Cells were analyzed using an Olympus FV1000 confocal microscope (Olympus, Tokyo, Japan).

\section{Measurement of the activity of $\beta 1$ integrin by immunoprecipitation}

Measurement of $\beta 1$ integrin activity by immunoprecipitation was performed as described previously $[45,46]$. Cells were inoculated on fibronectin-coated $(10 \mu \mathrm{g} /$ $\mathrm{mL}$ ) cell culture dishes, in the absence or presence of $20 \mu \mathrm{M}$ F806 for $24 \mathrm{hr}$. Cells were lysed in $4^{\circ} \mathrm{C}$ Triton lysis buffer (20 mM Tris-HCl, pH 7.4, 150 mM NaCl, 1\% Triton X-100, and $5 \mathrm{mM}$ EDTA) with $1 \mathrm{X}$ Halt Protease and Phosphatase Inhibitor Cocktail (Thermo Fisher Scientific Inc., 78441, Rockford, IL, USA). Cell lysates were immunoprecipitated with anti-active $\beta 1$ integrin (CHEMICON International, Inc., MAB2079Z, Billerica, MA, USA), rotating overnight at $4^{\circ} \mathrm{C}$. Immune complexes were sedimented (3000 rpm for 3 minute at $4^{\circ} \mathrm{C}$ ) and washed five times with ice-cold lysis buffer. The pelleted immune complexes were resuspended in $1 \times$ Laemmli sample buffer and boiled before being resolved by SDS-PAGE.

\section{Statistical analyses}

Data analysis was performed using SPSS 13.0 software (SPSS, Inc., Chicago, IL, USA). A two-way ANOVA was used to determine the significance of differences between groups and $P<0.05$ was deemed statistically significant. Data were plotted as mean \pm SD at least three independent experiments using GraphPad Prism 5 software (GraphPad Software, Inc., La Jolla, CA, USA).

\section{ACKNOWLEDGMENTS}

This work was supported by grants from the National $11^{\text {th }}$ Five-Year Plan major scientific and technological issues of China (No. 2009ZX9302-004), the Natural Science Foundation of China-Guangdong Joint Fund (No. U0932001 and No. U1301227) and the National Natural Science Foundation of China (No. 81172264, No. 81472613 and No. 81472342).

We thank Dr. Stanley Li Lin, Department of Pathophysiology, The Key Immunopathology Laboratory of Guangdong Province, Shantou University Medical College, for the assistance in revising the manuscript. We thank Dr. Wei-Jiang Zhao, Neural Science Center, Shantou University Medical College, for the assistance in completing the confocal microscopy study.

\section{REFERENCES}

1. Parkin DM, Bray F, Ferlay J, Pisani P. Global cancer statistics, 2002. CA Cancer J Clin. 2005; 55:74-108.
2. Ekman S, Dreilich M, Lennartsson J, Wallner B, Brattstrom D, Sundbom M, Bergqvist M. Esophageal cancer: current and emerging therapy modalities. Expert Rev Anticancer Ther. 2008; 8:1433-1448.

3. Jemal A, Siegel R, Ward E, Hao Y, Xu J, Thun MJ. Cancer statistics, 2009. CA Cancer J Clin. 2009; 59:225-249.

4. Ma WW, Adjei AA. Novel agents on the horizon for cancer therapy. CA Cancer J Clin. 2009; 59:111-137.

5. Hurwitz H, Fehrenbacher L, Novotny W, Cartwright T, Hainsworth J, Heim W, Berlin J, Baron A, Griffing S, Holmgren E, Ferrara N, Fyfe G, Rogers B, et al. Bevacizumab plus irinotecan, fluorouracil, and leucovorin for metastatic colorectal cancer. N Engl J Med. 2004; 350:2335-2342.

6. Cunningham D, Humblet Y, Siena S, Khayat D, Bleiberg H, Santoro A, Bets D, Mueser M, Harstrick A, Verslype C, Chau I, Van Cutsem E. Cetuximab monotherapy and cetuximab plus irinotecan in irinotecan-refractory metastatic colorectal cancer. N Engl J Med. 2004; 351:337-345.

7. Moore MJ, Goldstein D, Hamm J, Figer A, Hecht JR, Gallinger S, Au HJ, Murawa P, Walde D, Wolff RA, Campos D, Lim R, Ding K, et al. Erlotinib plus gemcitabine compared with gemcitabine alone in patients with advanced pancreatic cancer: a phase III trial of the National Cancer Institute of Canada Clinical Trials Group. J Clin Oncol. 2007; 25:1960-1966.

8. Adjei AA, Hidalgo M. Intracellular signal transduction pathway proteins as targets for cancer therapy. J Clin Oncol. $2005 ; 23: 5386-5403$.

9. Giancotti FG, Ruoslahti E. Integrin signaling. Science. 1999; 285:1028-1032.

10. Hynes RO. Integrins: bidirectional, allosteric signaling machines. Cell. 2002; 110:673-687.

11. Margadant C, Monsuur HN, Norman JC, Sonnenberg A. Mechanisms of integrin activation and trafficking. Curr Opin Cell Biol. 2011; 23:607-614.

12. Aoudjit F, Vuori K. Integrin signaling inhibits paclitaxelinduced apoptosis in breast cancer cells. Oncogene. 2001; 20:4995-5004.

13. Carbonell WS, DeLay M, Jahangiri A, Park CC, Aghi MK. beta1 integrin targeting potentiates antiangiogenic therapy and inhibits the growth of bevacizumab-resistant glioblastoma. Cancer Res. 2013; 73:3145-3154.

14. Kanda R, Kawahara A, Watari K, Murakami Y, Sonoda K, Maeda M, Fujita H, Kage M, Uramoto H, Costa C, Kuwano M, Ono M. Erlotinib resistance in lung cancer cells mediated by integrin beta1/Src/Akt-driven bypass signaling. Cancer Res. 2013; 73:6243-6253.

15. Jahangiri A, Aghi MK, Carbonell WS. betal integrin: Critical path to antiangiogenic therapy resistance and beyond. Cancer Res. 2014; 74:3-7.

16. Ip CK, Yung S, Chan TM, Tsao SW, Wong AS. p70 S6 kinase drives ovarian cancer metastasis through multicellular spheroid-peritoneum interaction and 
P-cadherin/b1 integrin signaling activation. Oncotarget. 2014; 5:9133-9149.

17. Elliott BE, Ekblom P, Pross H, Niemann A, Rubin K. Anti-beta 1 integrin IgG inhibits pulmonary macrometastasis and the size of micrometastases from a murine mammary carcinoma. Cell Adhes Commun. 1994; 1:319-332.

18. Park CC, Zhang H, Pallavicini M, Gray JW, Baehner F, Park CJ, Bissell MJ. Beta1 integrin inhibitory antibody induces apoptosis of breast cancer cells, inhibits growth, and distinguishes malignant from normal phenotype in three dimensional cultures and in vivo. Cancer Res. 2006; 66:1526-1535.

19. Barkan D, Chambers AF. beta1-integrin: a potential therapeutic target in the battle against cancer recurrence. Clin Cancer Res. 2011; 17:7219-7223.

20. Huang W, Jia W, Fu HL, Cheng H, Xu JH, Jiang H, Zheng W. Structure identifi cation and anti-tumor activity research of FW-04-806. Chin J Antibiot. 2011; 36:502-505.

21. Chen H, Jia W, Huang W, Fu H, Jiang H, Zheng W. Optimization of fermentation conditions for FW-04-806, a macrolide dilactone compound with two oxazole ring. Chin J Antibiot. 2012; 37:45-49.

22. Huang $\mathrm{W}$, Ye M, Zhang LR, Wu QD, Zhang M, Xu JH, Zheng W. FW-04-806 inhibits proliferation and induces apoptosis in human breast cancer cells by binding to N-terminus of Hsp90 and disrupting Hsp90-Cdc37 complex formation. Mol Cancer. 2014; 13:150.

23. Reddig PJ, Juliano RL. Clinging to life: cell to matrix adhesion and cell survival. Cancer Metastasis Rev. 2005; 24:425-439.

24. Frisch SM, Francis H. Disruption of epithelial cellmatrix interactions induces apoptosis. J Cell Biol. 1994; 124:619-626.

25. Schwartz MA, Assoian RK. Integrins and cell proliferation: regulation of cyclin-dependent kinases via cytoplasmic signaling pathways. J Cell Sci. 2001; 114:2553-2560.

26. Frisch SM, Screaton RA. Anoikis mechanisms. Curr Opin Cell Biol. 2001; 13:555-562.

27. Westley JW, Liu CM, Evans RH, Blount JF. Conglobatin, a novel macrolide dilactone from Streptomyces conglobatus ATCC 31005. J Antibiot (Tokyo). 1979; 32:874-877.

28. Hynes RO. Integrins: versatility, modulation, and signaling in cell adhesion. Cell. 1992; 69:11-25.

29. Frisch SM, Ruoslahti E. Integrins and anoikis. Curr Opin Cell Biol. 1997; 9:701-706.

30. Zhang X, Cheng SL, Bian K, Wang L, Zhang X, Yan B, Jia LT, Zhao J, Gammoh N, Yang AG, Zhang R. MicroRNA-26a promotes anoikis in human hepatocellular carcinoma cells by targeting alpha5 integrin. Oncotarget. 2014 Dec 10.

31. Shattil SJ, Kim C, Ginsberg MH. The final steps of integrin activation: the end game. Nat Rev Mol Cell Biol. 2010; 11:288-300.
32. Moser M, Legate KR, Zent R, Fassler R. The tail of integrins, talin, and kindlins. Science. 2009; 324:895-899.

33. Calderwood DA. Integrin activation. J Cell Sci. 2004; 117:657-666.

34. Luo BH, Springer TA. Integrin structures and conformational signaling. Curr Opin Cell Biol. 2006; 18:579-586.

35. Gahmberg CG, Fagerholm SC, Nurmi SM, Chavakis T, Marchesan S, Gronholm M. Regulation of integrin activity and signalling. Biochim Biophys Acta. 2009; 1790:431-444.

36. Wu Y, Chen L, Zheng PS, Yang BB. beta 1-Integrinmediated glioma cell adhesion and free radical-induced apoptosis are regulated by binding to a $\mathrm{C}$-terminal domain of PG-M/versican. J Biol Chem. 2002; 277:12294-12301.

37. Reardon DA, Cheresh D. Cilengitide: a prototypic integrin inhibitor for the treatment of glioblastoma and other malignancies. Genes Cancer. 2011; 2:1159-1165.

38. Hanahan D, Weinberg RA. Hallmarks of cancer: the next generation. Cell. 2011; 144:646-674.

39. Vredenburgh JJ, Desjardins A, Herndon JE 2nd, Dowell JM, Reardon DA, Quinn JA, Rich JN, Sathornsumetee S, Gururangan S, Wagner M, Bigner DD, Friedman AH, Friedman HS. Phase II trial of bevacizumab and irinotecan in recurrent malignant glioma. Clin Cancer Res. 2007; 13:1253-1259.

40. Bergers G, Hanahan D. Modes of resistance to anti-angiogenic therapy. Nat Rev Cancer. 2008; 8:592-603.

41. Ebos JM, Lee CR, Kerbel RS. Tumor and host-mediated pathways of resistance and disease progression in response to antiangiogenic therapy. Clin Cancer Res. 2009; 15:5020-5025.

42. Azam F, Mehta S, Harris AL. Mechanisms of resistance to antiangiogenesis therapy. Eur J Cancer. 2010; 46:1323-1332.

43. Kienast Y, Winkler F. Therapy and prophylaxis of brain metastases. Expert Rev Anticancer Ther. 2010; 10:1763-1777.

44. Xie JJ, Xu LY, Wu JY, Shen ZY, Zhao Q, Du ZP, Lv Z, $\mathrm{Gu}$ W, Pan F, Xu XE, Xie D, Li EM. Involvement of CYR61 and CTGF in the fascin-mediated proliferation and invasiveness of esophageal squamous cell carcinomas cells. Am J Pathol. 2010; 176:939-951.

45. Serini G, Valdembri D, Zanivan S, Morterra G, Burkhardt C, Caccavari F, Zammataro L, Primo L, Tamagnone L, Logan M, Tessier-Lavigne M, Taniguchi M, Püschel AW, et al. Class 3 semaphorins control vascular morphogenesis by inhibiting integrin function. Nature. 2003; 424:391-397.

46. Oinuma I, Katoh H, Negishi M. Semaphorin 4D/PlexinB1-mediated R-Ras GAP activity inhibits cell migration by regulating beta(1) integrin activity. J Cell Biol. 2006; 173:601-613. 